\title{
NOTE AUX AUTEURS
}

Lusotopie publie des articles en français, portugais et anglais, soumis à évaluation. Il s'agit d'originaux (sauf exceptionnelles traductions d'articles déjà publiés en d'autres langues). Les articles ne dépassent pas 40000 signes (6 5000 mots), sur disquette, ou fichier attaché via internet, de préférence Word sur Mac, à défaut sur un autre traitement de texte courant avec mention exacte du système, de l'application et de sa version (ex. : PC Word $5.1)$.

Attention, il n'y a pas de renvois d'épreuves aux auteurs à Lusotopie

C'est avant la confection des épreuves que nous pouvons vous renvoyer votre manuscrit pour modifications. La rédaction se réserve le droit de faire des corrections grammaticales et stylistiques mineures, de mettre des titres de partie s'ils font défaut, de modifier les résumés.

\section{Impératifs}

1) Les citations doivent être suivies de leur référence précise : auteur, ouvrage et page. Les références bibliographiques, qu'elles soient citées en note, en bibliographie, dans les tableaux ou annexes, etc., doivent comporter :

- obligatoirement le nom de l'auteur et l'initiale du prénom; le titre exact du document (avec le sous-titre éventuellement); la ville de publication du livre ou de la revue ; le nom de la maison d'édition ; l'année de publication; pour les articles, le vo-lume (éventuellement) et le numéro de la revue et son lieu d'édition; la pagination; pour les contributions à des ouvrages collectifs, la pagination de la contribution; pour les docu-ments non publiés, indiquer la mention multigr.

- si possible la collection; pour la littérature grise (documents non publiés) donner le maximum d'indications permettant de localiser

2) Si vous faites une bibliographie finale, les références y figureront sous cette forme selon qu'il s'agit d'ouvrages, d'articles, de contributions à ouvrage collectif, ou de thèses et rapports non publiés :

- Ex. : Axel, J.-V. \& Kahn, C., eds. 1990, Les hauts de la ville. Essais sur Douala, Paris, Plon, 213 p., bibl., cartes, ill., index («Poche-Plon », 13).

- Ex. : Axel, J. 1995, «Pourquoi la ville? Douala entre deux eaux», Revue de Géographie (Lyon), XII (3): 25-47, bibl.

- Ex. : Lavaud, J.-F. 1993, «Détruire, dit-elle », in A. LÉotard \& J. François (eds), Construire l'avenir ?, SaintFlour (France), Éditions du Coin : 123-154.

- Ex. : PÉNot, É. 1995, La riziculture de mangrove balante, communication au colloque "Quel avenir pour les rizicultures de l'Afrique de l'Ouest? ", Bordeaux, CNRS (Centre national de la recherche scientifique), 4-7 avril 1995, 25 p. multigr.

- Dans le texte elles seront limitées au nom de l'auteur, à la date et au besoin à la pagination, entre parenthèses :

- Ex. : «... comme le disent deux auteurs (Heim 1975; Dejours 1976 : 1-5) ...».

3) Si les références sont uniquement en notes (pas de bibliographie séparée), l'ordre est le suivant:

- Ex. : M. Foucault, Il faut défendre la société, Paris, Fayard, 1996, 254 p.

- Ex. pour les références à un titre déjà cité : M. Foucault, Il faut défendre...., op. cit. : 213.

Sigles. Pas de points (PALOP et non P.A.L.O.P.). Signification à donner la première fois où ils sont utilisés, entre parenthèses, y compris dans les bibliographies (PS, Partido socialista). En français et portugais, on ne met de majuscule initiale qu'au premier mot (Comunidade dos países de língua portuguesa).

Langues étrangères à l'article. Les termes ou citations qui ne sont pas dans la langue de l'article doivent être en italiques et traduits, sauf exceptions justifiées par des difficultés de sens. Dans ce cas, la traduction doit être donnée en note.

Sous-titres de parties. À utiliser au moins toutes les trois pages, sinon le comité de rédaction en inventera! Sous-titres et sous-sous-titres doivent être clairement distingués par la typographie.

Notes. Ordinateur: présenter en numérotation continue (et non en numérotation page par page). Machines à écrire: vérifier que notes et appels de notes correspondent bien.

Tableaux, figures, illustrations, etc. Ils doivent comporter un titre et la mention de leur(s) source $(\mathrm{s})$ avec référence bibliographique complète. Les notes des tableaux ne font pas partie de la numérotation continue (les indiquer sous le tableau par astérisques ou les numéroter).

Résumé obligatoire, si possible trilingue, d’une dizaine de lignes, rédigé en style impersonnel.

Date et appartenance. Dater la rédaction de l'article et indiquer votre appartenance universitaire ou institutionnelle et son lieu d'implantation. Éventuellement: votre adresse électronique.

Adresse de la rédaction : Comité de rédaction de Lusotopie, Maison des Suds-CNRS, 12 Esplanade des Antilles, 33607-Pessac cedex, France.

Le fait d'accepter la publication d'un article dans Lusotopie vaut tant pour la revue que pour son site en ligne, ou tout autre site avec lequel Lusotopie aura passé un accord sans but lucratif. 


\section{NOTA AOS AUTORES}

Lusotopie publica artigos em francês, português e inglês, após exame pelo comitê de leitura. Trata-se de originais (salvo excepcionalmente traduções de artigos já publicados em outras línguas). Os artigos não devem ultrapassar 40000 sinais (6 500 palavras), em disquete ou arquivo anexado via internet, de preferência em Word Mac, ou então em outro processamento de texto corrente com a menção exata do sistema, da aplicação e de sua versão (ex. : PG Word 5.1).

\section{Atenção: Nãa há correção de provas pelos autores em Lusotopie}

É antes da confecção das provas que podemos reexpedir seu manuscrito par modificações. A redação reservase o direito de efetuar correções gramaticais e estilísticas menores, colocar títulos nas diferentes partes, se não existirem, modificar os resumos.

\section{Requisitos}

1) As citações devem acompanhar-se de suas referências precisas: autor, obra e página. As referências bibliográficas, sejam elas citadas em nota, na bibliografia, quadros ou anexos, etc., devem comportar :

- obrigatoriamente, o sobrenome do autor e a inicial do nome; a cidade onde o livro ou a revista foi publicado; o nome da editora; o ano de publicação ; o título exato do documento (eventualmente com o subtítulo) ; para os artigos, o volume (eventualmente) e o número da revista e seu local de edição ; a paginação ; para as contribuições em obras coletivas, a pa-ginação da contribuição; para os documentos não publicados, acrescentar a menção mimeo.;

- se possível a coleção, para os documentos inéditos ; fornecer o máximo de informações que permitam localizar os textos.

2) É possível fazer uma bibliografia final, sobretudo se esta for muito longa. Nesse caso, as refe-rências nela figurarão na forma abaixo, segundo se tratar de obras, artigos, contribuições numa obra coletiva, ou teses e relatórios não publicados :

- Ex. : Axel, J.-V. \& Kann, C., eds. 1990, Les hauts de la ville. Essais sur Douala, Paris, Plon, 213 p., bibl., mapas, il., index (coll. «Poche-Plon», $\mathrm{n}^{\circ} 13$ ).

- Ex. : Axel, J. 1995 «Pourquoi la ville? Douala entre deux eaux », Revue de Géographie (Lyon), XII (3) : 25-47, bibl.

- Ex. : Lavaud, J.-F. 1993, «Détruire, dit-elle », in A. LÉotard \& J. François (eds), Construire l'avenir ?, Saint-Flour (França), Editions du Coin : 123-154.

- Ex. : PÉnot, E. 1995, La riziculture de mangrove balante, comunicação ao colóquio "Quel avenir pour les rizicultures de l'Afrique de l'Ouest? ", Bordéus, CNRS (Centre national de la recherche scientifique), 4-7 de Abril 1995, 25 p. mimeo.

- No texto, elas se limitarão ao nome do autor, data e, caso necessário, paginação, entre parênteses :

- Ex. : «... comme le disent deux auteurs (Heim 1975; Dejours 1976: 1-5) . . ».

3) Para as bibliografias em notas de rodapé, respeitar as seguintes regras:

- Ex. : M. Foucault, Il faut défendre la société, Paris, Fayard, 1996, 254 p.

- Ex. para as referências a um título já citado: M. Foucault, Il faut défendre ..., op. cit. : 213.

Siglas. Não utilizar pontos (PALOP e não P.A.L.O.P.). Significação a mencionar na primeira vez que forem utilizadas, entre parênteses, inclusive nas bibliografias (PS, Partido socialista). Em francês e em português, só se coloca a maiúscula na primeira palavra (Comunidade dos países de língua portuguesa).

Línguas estrangeiras ao artigo. Os termos ou citações que não estiverem na língua do artigo devem figurar em itálico e ser traduzidos, salvo exceções justificadas por dificuldades de sentido. Nesse caso, a tradução deve figurar em nota.

Subtitulos das partes. A utilizar pelo menos a cada três páginas ; caso contrário, o comitê de redação os inventará! Subtítulos e sub-subtítulos devem se distinguir claramente pela tipografia.

Notas. Computador: apresentar em numeração contínua (e não em numeração página a página).

Quadros, figuras, ilustrações, etc. Devem comportar um título e a menção de sua(s) fonte(s), com referência bibliográfica completa. As notas dos quadros não fazem parte da numeração contínua (indicá-los sob o quadro por asteriscos ou numerálos).

Resumo obrigatório, se possível trilingüe, de umas dez linhas, redigido em estilo impessoal.

Data e vinculação. Datar a redação do artigo, indicar sua vinculação universitária ou institucional, precisando o local de implantação.

Comité de redacção de Lusotopie, Comité de rédaction de Lusotopie, Maison des Suds-CNRS, 12 Esplanade des Antilles, 33607-Pessac cedex, França.

O facto, por parte do autor, de aceitar a publicação de um artigo na Lusotopie, implica o seu acordo tanto para a revista como para a inserção no site web, ou outros sites na web, baseado num acordo sem fins lucrativos com Lusotopie. 


\section{NOTE TO GONTRIBUTORS}

Lusotopie publishes articles in French, Portuguese, and English, after evaluation. The work published is original (except, in special cases, for translations of articles previously published in other languages). Articles must not exceed 40,000 signs (6,500 words), and may be submitted on disk or as an email attachment. The preferred format is a Macintosh Word document, but other commonly used word-processing formats are acceptable provided that you clearly specify the system, software name and version (e.g. PC Word 5.1).

\section{Please note that Lusotopie does not correct proofs}

We can only send your text back to you for changes before the proofs are made. The editorial board reserves the right to make minor corrections in matters of grammar and style, to add section headings where lacking, and to modify abstracts.

\section{BIBLIOGRAPHIGAL REFERENGES}

1) Lusotopie prefers bibliographical references to be made in footnotes according to the following rules:

- E.g. : M. Foucault, Il faut défendre la société, Paris, Fayard, 1996, 254 p.

- E.g. for references to a work already cited: M. Foucault, Il faut défendre . . ., op. cit.: 213.

Works cited must be followed by their precise reference: author, title, and page number. Bibliographical references, whether cited in a footnote, a bibliography, a table, or an appendix (or anywhere else), must include:

- necessarily the author's name and first initial, the city where the book or journal was published, the publisher's name, the date of publication, the exact title of the document (and possibly its sub-title); for articles, the volume number (where possible), the journal number, and the place of publication; the page numbers; for collaborative publications, the page numbers of the contribution; for unpublished documents, indicate mimeo.

- where possible the series name; for unpublished documents, provide as much information as possible to allow it to be found.

2) It is possible to include a bibliography at the end, especially if it is a long one. In this case, the references appearing in it will take the following form, according to whether they are books, articles, contributions to a collaborative work, doctoral dissertations or unpublished reports:

- E.g. : Axel, J.-V. \& Kann, C., eds. 1990, Les hauts de la ville. Essais sur Douala, Paris, Plon, 213 p., bibl., maps, ill., index (coll. «Poche-Plon », $\mathrm{n}^{\circ} 13$ ).

- E.g. : Axel, J. 1995 «Pourquoi la ville? Douala entre deux eaux», Revue de Géographie (Lyon), XII (3): 25-47, bibl.

- E.g. : Lavaud, J.-F. 1993, «Détruire, dit-elle », in A. LÉotard \& J. François (eds), Construire l'avenir ?, SaintFlour (France), Editions du Coin : 123-154.

- E.g. : PÉnOt, É. 1995, La riziculture de mangrove balante, paper delivered at the conference "Quel avenir pour les rizicultures de l'Afrique de l'Ouest?", Bordeaux, CNRS (Centre national de la recherche scientifique), April 4-7, 1995, 25 p. mimeo.

Citations within the text are limited to the author's name, the date, and pages when necessary, in parentheses:

- E.g. : «. . . as has been said by two authors (Heim 1975 ; Dejours 1976 : 1-5) . .».

\section{AGRONYMS, TABLES, ETG...}

Acronyms. Do not punctuate (PALOP and not P.A.L.O.P.). Indicate what they stand for in parentheses the first time they are used, including in bibliographies (PS, Partido socialista). In French and Portuguese, only the first word is capitalized (Comunidade dos países de língua portuguese).

Foreign language terms. Terms or citations in a language other than that of the article must be in italics and translated, except when the meaning is difficult to render. In that case the translation is to be provided in a note. Section headings. Section headings are to be used at least every three pages; otherwise the editorial committee will create them! Section and sub-section headings must be clearly distinguished by their typography.

Notes. Computer: Use successive numbering (i.e. do not use new numbering for each page).

Tables, figures, illustrations, etc. They must have a title and a reference to their source(s) with a complete bibliographical citation. The notes for tables do not belong to the successively numbered notes of the main text (indicate notes to a table by asterisks or their own numbering).

Abstract required, if possible in all three languages, 10 lines long, composed in impersonal style.

Date and affiliation. Indicate the article's completion date and the university or institution to which you are affiliated and its location.

Editorial Board of Lusotopie: Comité de rédaction de Lusotopie, Maison des Suds-CNRS, 12 Esplanade des Antilles, 33607-Pessac cedex, France.

By agreeing to publish an article in Lusotopie, an author gives agreement for publication in the paper edition of the journal as well as in the Lusotopie on-line edition or in other non-profit websites linked by agreement with Lusotopie. 